\title{
Antagonistic effects of leucine and glutamine on the mTOR pathway in myogenic $C_{2} C_{12}$ cells
}

\author{
L. Deldicque ${ }^{1}$, C. Sanchez Canedo ${ }^{2}$, S. Horman ${ }^{3}$, I. De Potter ${ }^{3}$, L. Bertrand ${ }^{2}$, L. Hue ${ }^{3}$, and M. Francaux ${ }^{1}$ \\ ${ }^{1}$ Département d'Education Physique et de Réadaptation, Université catholique de Louvain, Louvain-la-Neuve, Belgium \\ ${ }^{2}$ Division of Cardiology, Université catholique de Louvain, Brussels, Belgium \\ ${ }^{3}$ Unité Hormones et Métabolisme, Institut de Pathologie Cellulaire Christian de Duve, Université catholique de Louvain, Brussels, Belgium
}

Received July 20, 2007

Accepted September 17, 2007

Published online November 5, 2007; (C) Springer-Verlag 2007

\begin{abstract}
Summary. This study compared the effects of leucine and glutamine on the mTOR pathway, on protein synthesis and on muscle-specific gene expression in myogenic $\mathrm{C}_{2} \mathrm{C}_{12}$ cells. Leucine increased the phosphorylation state of mTOR, on both Ser2448 and Ser2481, and its downstream effectors, $\mathrm{p} 70^{\mathrm{S} 6 \mathrm{k}}, \mathrm{S} 6$ and 4E-BP1. By contrast, glutamine decreased the phosphorylation state of mTOR on Ser2448, p70 ${ }^{\mathrm{S} 6 \mathrm{k}}$ and 4E-BP1, but did not modify the phosphorylation state of mTOR on Ser2481 and S6. Whilst the phosphorylation state of the mTOR pathway is usually related to protein synthesis, the incorporation of labelled methionine/cysteine was only transiently modified by leucine and was unaltered by glutamine. However, these two amino acids affected the mRNA levels of desmin, myogenin and myosin heavy chain in a timedependant manner. In conclusion, leucine and glutamine have opposite effects on the mTOR pathway. Moreover, they induce modification of muscle-specific gene expression, unrelated to their effects on the $\mathrm{mTOR} / \mathrm{p} 70^{\mathrm{S} 6 \mathrm{k}}$ pathway.
\end{abstract}

Keywords: Amino acids $-\mathrm{p} 70^{\mathrm{S} 6 \mathrm{k}}-4 \mathrm{E}-\mathrm{BP} 1$ - protein synthesis - gene expression

\section{Introduction}

Amino acids are the building blocks for protein synthesis which they are also able to regulate by modulating signalling pathways. In many cell types, amino acids increase the phosphorylation state of p70 ribosomal S6 kinase $\left(\mathrm{p} 70^{\mathrm{S} 6 \mathrm{k}}\right)$ and eukaryotic initiation factor 4E-binding protein 1 (4E-BP1), two proteins downstream of the mammalian target of rapamycin (mTOR) and playing a key role in the control of protein synthesis initiation (for review see Proud, 2002; Jefferson and Kimball, 2003; Deldicque et al., 2005). The way by which amino acids stimulate $\mathrm{p} 70^{\mathrm{S} 6 \mathrm{k}}$ and $4 \mathrm{E}-\mathrm{BP} 1$ is not fully understood but clearly involves the mTOR pathway, which senses nutrients and regulates transcription, translation and protein degradation (Rohde et al., 2001).

Leucine, a branched chain amino acid, seems to be a particularly effective anabolic agent. It is known to activate $\mathrm{p} 70^{\mathrm{S} 6 \mathrm{k}}$ in hepatocytes (Krause et al., 2002), pancreatic beta cells (Xu et al., 1998) and adipocytes (Fox et al., 1998). Leucine also increases the phosphorylation state of $\mathrm{p} 70^{\mathrm{S} 6 \mathrm{k}}$ in proliferating L6 (Kimball et al., 1999) and $\mathrm{C}_{2} \mathrm{C}_{12}$ myogenic cells (Du et al., 2007). Recently, Nakajo et al. (2005) have studied the effect of 14 amino acids on $\mathrm{p} 70^{\mathrm{S} 6 \mathrm{k}}$ activity in intestinal epithelial cells. In this cell type, both leucine and arginine activated $\mathrm{p} 70^{\mathrm{S} 6 \mathrm{k}}$ whereas glutamine did not modify its activity. By contrast, glutamine reversed the activation of $\mathrm{p} 70^{\mathrm{S} 6 \mathrm{k}}$ induced by leucine and arginine when it was combined with one of these two amino acids. Unlike in hepatocytes (Krause et al., 2002), in which glutamine is able to activate $\mathrm{p} 70^{\mathrm{S} 6 \mathrm{k}}$ alone or in combination with leucine, glutamine negatively regulated the mTOR pathway in intestinal epithelial cells (Nakajo et al., 2005).

In addition to controlling protein translation and more particularly $\mathrm{p} 70^{\mathrm{S} 6 \mathrm{k}}$ and $4 \mathrm{E}-\mathrm{BP} 1$, evidence that amino acids may also induce or repress gene transcription is growing. Amino acid deprivation upregulates genes involved in nutrient catabolism and energy production and downregulates genes participating in lipid and nucleotide synthesis and in protein synthesis, turnover and folding (Peng et al., 2002). In myogenic cells, amino acid sufficiency is required to activate IGF-II transcription via the mTOR pathway leading to enhanced differentiation (Erbay et al., 2003). Recent- 
ly, the mTOR pathway has been found to be critical in the cardiac transcriptional response to glutamine. The addition of glutamine to cultured rat cardiomyocytes increased abundance of the mRNAs encoding contractile proteins and metabolic enzymes through the protein kinase A and mTOR cascades (Xia et al., 2003).

Since the effect of amino acids on the phosphorylation state of $\mathrm{p} 70^{\mathrm{S} 6 \mathrm{k}}$ has been reported in several cell types, but only a few papers present data supporting a stimulation of protein synthesis (Kimball et al., 1999; Mordier et al., 2000; Du et al., 2007), the purpose of the present work was to analyze the effect of leucine and glutamine on several proteins constituting or regulating the mTOR signalling pathway and their ability, separately or in combination, to modify the protein synthesis rate in differentiating myogenic $\mathrm{C}_{2} \mathrm{C}_{12}$ cells. Since labelled methionine/cysteine incorporation was only affected to a minor extent by leucine, the second purpose of this work was to test if the changes observed in $\mathrm{p} 70^{\mathrm{S} 6 \mathrm{k}}$ phosphorylation could alter gene expression.

\section{Materials and methods}

\subsection{Cell culture}

$\mathrm{C}_{2} \mathrm{C}_{12}$ murine skeletal muscle myoblasts (ATCC) were seeded in Petri culture dishes. They were grown in DMEM (Dulbecco's modified Eagle's medium, Life Technologies) supplemented with $10 \%$ fetal bovine serum, penicillin/streptomycin $(5000 \mathrm{U} / 5000 \mu \mathrm{g} / \mathrm{ml})$ and $100 \mu \mathrm{M}$ non-essential amino acids. When cells were $70 \%$ confluent, the proliferation medium was replaced by a differentiation medium containing $1 \%$ horse serum. After $48 \mathrm{~h}$ of differentiation, cells were incubated for $1 \mathrm{~h}$ with serum-free DMEM lacking leucine and glutamine (Life Technologies). Leucine ( $5 \mathrm{mM})$, glutamine ( $5 \mathrm{mM}$ ) or both ( $5 \mathrm{mM}$ each) (Sigma) were then added to the plates.

Phosphorylation states and protein synthesis. Cells were lysed after $30 \mathrm{~min}, 3 \mathrm{~h}$ and $24 \mathrm{~h}$, in a buffer (pH 7.0) containing $20 \mathrm{mM}$ Tris, $270 \mathrm{mM}$ sucrose, 5 mM EGTA, 1mM EDTA, $1 \%$ Triton X-100, 1 mM sodium orthovanadate, $50 \mathrm{mM}$ sodium $\beta$-glycerophosphate, $5 \mathrm{mM}$ sodium pyrophosphate, $50 \mathrm{mM}$ sodium fluoride, $1 \mathrm{mM}$ 1,4-dithiothreitol and a protease inhibitor cocktail (Roche Applied Science). The supernatants $(10,000 \mathrm{~g}$, $10 \mathrm{~min}$ ) were stored at $-80^{\circ} \mathrm{C}$ and protein concentration was determined using the DC protein assay kit (Bio-Rad Laboratories) with BSA as standard.

$m R N A$ levels. Cells were homogenized in $500 \mu 1$ TRIZOL $^{\circledR}$ after 1,3 and $24 \mathrm{~h}$ of incubation with leucine and/or glutamine. Total RNA was extracted according to the instructions provided by the manufacturer (Invitrogen). RNA was quantified by spectrophotometry $(260 \mathrm{~nm})$ and its concentration adjusted to $1 \mu \mathrm{g} / \mu \mathrm{l}$ using RNase-free water.

\subsection{SDS/PAGE and immunoblotting}

Proteins were separated by SDS/PAGE and transferred to a PVDF (Polyvinylidene Difluoride) membrane for immunoblot analysis except for 4EBP1, which was transferred to a nitrocellulose membrane. Membranes were then incubated in a $5 \%$ Blotto solution. The following phosphospecific antibodies were added and incubated overnight at $4{ }^{\circ} \mathrm{C}$ in Blotto or in TBST (Tris-buffered saline with Tween-20) containing 1\% BSA: mTOR (Ser 2448, Ser 2481; Cell Signalling), p70 ${ }^{\text {S6k }}$ (Thr 389; Santa Cruz), 4E-BP1 (Calbiochem), S6 (Ser235/236; Cell Signalling), eEF2 (Thr 56, provided by V. Stroobant from the Ludwig Institute, Brussels,
Belgium) and eIF2B (Ser 535, Biosource) (Some abbreviations are defined in the legends to Figs. 4 and 6). Membranes were then incubated for $1 \mathrm{~h}$ at room temperature in secondary antibody conjugated to horseradish peroxidase (1:10000) in a 5\% Blotto solution. Chemiluminescent detection was carried out using an ECL Western blotting kit (Amersham Biosciences). Then, the membranes were stripped and re-probed with a total antibody (total mTOR, Cell Signalling; total $\mathrm{p} 70^{\mathrm{S} 6 \mathrm{k}}$, Santa Cruz) to verify the relative amount of the analyzed proteins through the experiment. The films were scanned on an ImageScanner using the Labscan software (Amersham Biosciences) and quantified with the Image Master 1D Image Analysis Software (Amersham Biosciences). The results represent the phosphorylated form of the protein.

\subsection{Protein kinase B activity}

Protein kinase B (PKB) activity was measured by the phosphorylation of a synthetic peptide after immunoprecipitation $(100 \mu \mathrm{g}$ of protein extract) with a total PKB antibody recognizing the PH-domain (Upstate Cell Signalling) as previously described (Bertrand et al., 1999). To summarize, the assay was performed in a final volume of $50 \mu \mathrm{l}$ in the presence of $10 \mathrm{mM}$ MOPS (pH 7.0), $0.5 \mathrm{mM}$ EDTA, $10 \mathrm{mM}$ Mg-acetate, $0.1 \%$ $\beta$-mercaptoethanol, $0.1 \mathrm{mM} \quad \mathrm{Mg}-\left[\gamma_{-}{ }^{32} \mathrm{P}\right]$ ATP (specific radioactivity $1000 \mathrm{cpm} / \mathrm{pmol}$, Amersham Biosciences) and $0.25 \mathrm{mM}$ substrate peptide RPRAATF (Alessi et al., 1996). The reaction was continued for $20 \mathrm{~min}$ at $30^{\circ} \mathrm{C}$. The supernatant was then spotted on to $\mathrm{P} 81$ phosphocellulose paper, followed by washes in cold $75 \mathrm{mM}$ phosphoric acid. ${ }^{32} \mathrm{P}$ incorporation was counted in a scintillation counter (LS 6500, Beckman) for 1 min.

\subsection{Adenosine monophosphate-activated protein kinase activity and acetyl-CoA carboxylase phosphorylation}

Total adenosine monophosphate-activated protein kinase (AMPK) activity was measured according to the method described by Marsin et al. (2000). Acetyl-CoA carboxylase (ACC) phosphorylation, which is the best known substrate of AMPK, was assessed by immunoblotting to confirm the results on the AMPK activity (anti-phospho specific Ser 79 ACC was a generous gift from D. G. Hardie, Dundee, Scotland).

\subsection{Incorporation of labelled $\left[{ }^{35}\right.$ S] methionine/cysteine}

Cells were grown in serum-free DMEM for $1 \mathrm{~h}$ before the experiment. Cells were then preincubated with $1 \mathrm{mM}$ unlabelled methionine/cysteine and with either $5 \mathrm{mM}$ leucine or $5 \mathrm{mM}$ glutamine, alone or in combination for $15 \mathrm{~min}$. After the preincubation period, $20 \mu \mathrm{l}$ of a protein labelling mix (EasyTag ${ }^{\mathrm{TM}}$ Express Protein Labelling Mix, $\left.{ }^{35} \mathrm{~S}\right]$ methionine/cysteine mixture, NEN Life Science Products) were added to each plate. Cells were lysed after $30 \mathrm{~min}, 3 \mathrm{~h}$ and $24 \mathrm{~h}$, centrifuged and proteins were precipitated with $10 \%$ trichloroacetic acid. The precipitated proteins were dissolved in $0.1 \mathrm{~N} \mathrm{NaOH}$ and precipitated again. The final pellet was resuspended in $800 \mu \mathrm{l}$ of formic acid. $5 \mathrm{ml}$ of scintillating liquid (Ultimagold, Perkin Elmer) was then added and ${ }^{35} \mathrm{~S}$ incorporation was counted in a scintillation counter (LS 6500, Beckman) for $1 \mathrm{~min}$.

\subsection{Real time RT-PCR analyses}

Reverse transcription (RT) was performed using the iScript synthesis kit (Bio-Rad) on a MyIQ thermal cycler (Bio-Rad) with $1 \mu \mathrm{g}$ of total RNA in a reaction volume of $20 \mu \mathrm{l}(4 \mu \mathrm{l}$ iScript reaction mix $5 \times, 1 \mu \mathrm{l}$ iScript reverse transcriptase, $1 \mu \mathrm{l}$ RNA template, $14 \mu \mathrm{l}$ RNase-free water). Primers were designed (Table 1) for mouse desmin, myogenin, caveolin 3 and myosin heavy chain type II (MHC II) and $\beta$-actin. Quantitative real-time polymerase chain reaction (PCR) was performed with the Sybr Green ${ }^{\circledR}$ PCR Core kit or master mix (Eurogentec) on a MyIQ thermal cycler (Bio$\mathrm{Rad}$ ) using the following cycle conditions: $10 \mathrm{~min}$ at $95^{\circ} \mathrm{C}$, followed by 40 cycles of $1 \mathrm{~min}$ at $60^{\circ} \mathrm{C}$ and $15 \mathrm{sec}$ at $95^{\circ} \mathrm{C}$. For each gene, real time RT$\mathrm{PCR}$ was conducted in duplicate. The $\Delta \mathrm{Ct}$ values were calculated in every 
Table 1. Primer sequences

\begin{tabular}{lll}
\hline & Forward & Reverse \\
\hline Desmin & CAGGACCTGCTCAATGTGAA & GCTGGTTTCTCGGAAGTTGA \\
Myogenin & GTGCCCAGTGAATGCAACTC & ACGATGGACGTAAGGGAGTG \\
Caveolin 3 & GCTCGGATCATCAAGGACAT & ACCTTCCATACACCGTCGAA \\
MHC II & GAACCCTCCCAAGTACGACA & GCATAACGCTCTTTGAGGTTG \\
$\beta$-actin & TCCTGAGCGCAAGTACTCTGT & CTGATCCACATCTGCTGGAAG
\end{tabular}

Sequences of primers $\left(5^{\prime}-3^{\prime}\right)$ used for mRNA quantification by real-time RT-PCR. MHC II, myosin heavy chain type II

sample for each gene of interest as follows: $\mathrm{Ct}_{\text {gene of interest }}-\mathrm{Ct}_{\text {reporter gene }}$ with $\beta$-actin as the reporter gene. Calculation of relative changes in the expression level of one specific gene $(\Delta \Delta \mathrm{Ct})$ was performed by subtraction of $\Delta \mathrm{Ct}$ from the control conditions to the corresponding $\Delta \mathrm{Ct}$ from the leucine and/or glutamine conditions. The mRNA results are presented as $2^{-\Delta \Delta \mathrm{Ct}}$.

\subsection{Statistical analysis}

The effect of leucine and glutamine was tested by unpaired Student's $t$ test. The significance threshold was set to $P<0.05$. The results are presented as the means \pm SEM.

\section{Results}

\subsection{Opposite effects of leucine and glutamine on the MTOR pathway}

Incubation of $\mathrm{C}_{2} \mathrm{C}_{12}$ cells for $30 \mathrm{~min}$ in the differentiation medium supplemented with $5 \mathrm{mM}$ leucine increased more than 10 fold the phosphorylation state of $\mathrm{p} 70^{\mathrm{S} 6 \mathrm{k}}$ on Thr $389(P<0.01$, Fig. 1A) and almost doubled the percentage of 4E-BP1 in the phosphorylat-
Phosphorylation of $\mathrm{p} 70^{\mathrm{s} 6 \mathrm{k}}$ Thr 389 (foldbasal)

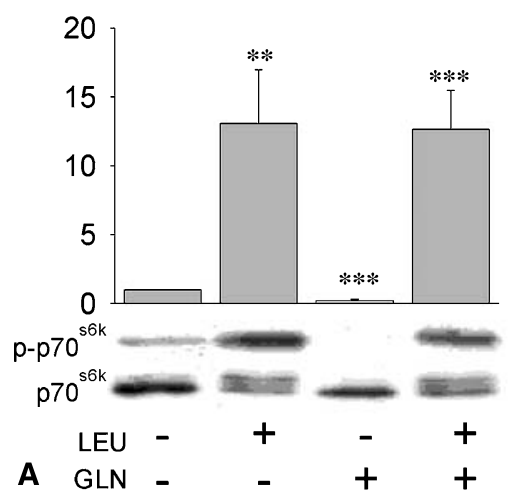

Phosphorylation of mTOR Ser 2481 (foldbasal)
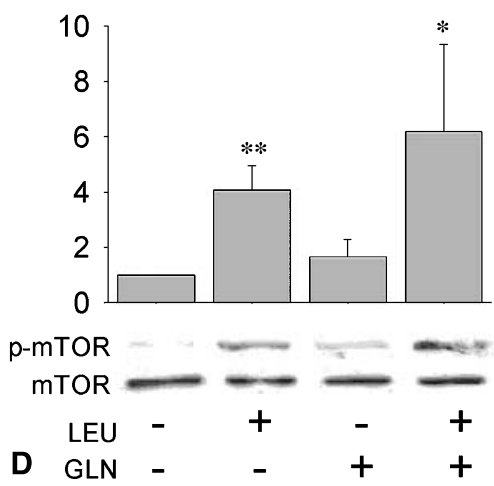

4E-BP1 in gamma form (foldbasal)
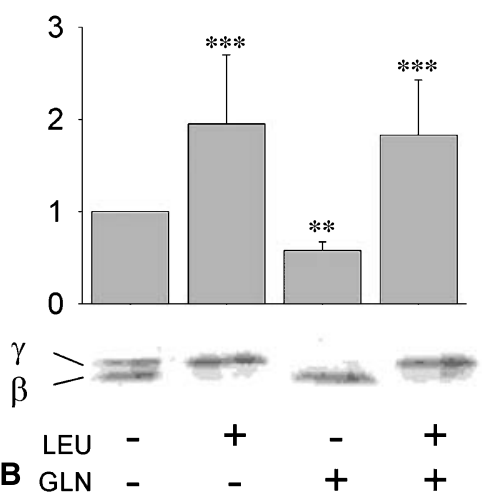

Phosphorylation of $\mathrm{S} 6$ Ser 235/236 (foldbasal)

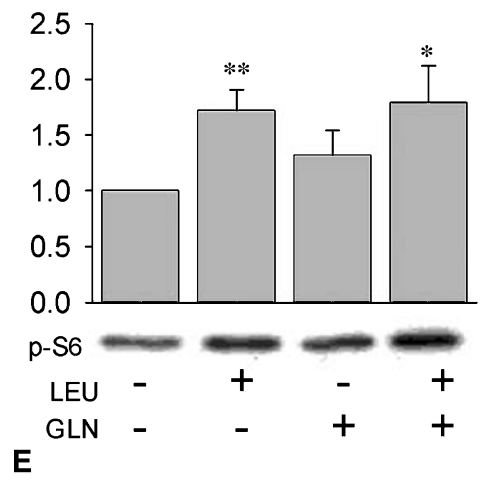

Phosphorylation of mTOR Ser 2448 (foldbasal)

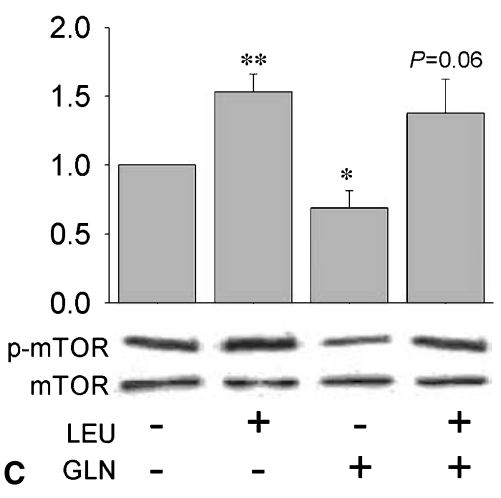

Phosphorylation of eEF2 Ser 56 (foldbasal)

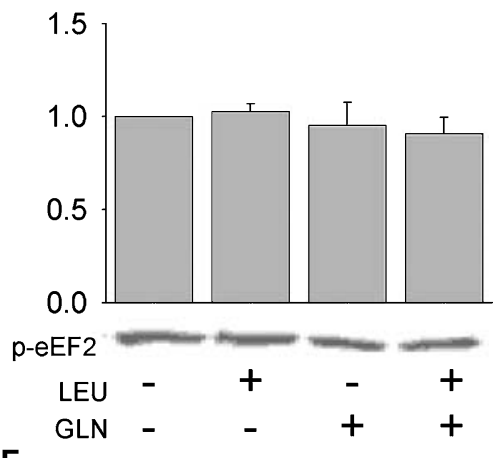

Fig. 1. Effect of leucine, glutamine, alone or in combination, on the phosphorylation state of the mTOR pathway. Phosphorylation state of p70 ${ }^{\mathrm{S} 6 \mathrm{k}}$ (A), 4E-BP1 (B), mTOR (C and D), S6 (E) and eEF2 (F) after incubation with leucine $(L E U)$ and/or glutamine $(G L N)$ for 30 min. Results are expressed as the means $\pm \operatorname{SEM}\left(n=8\right.$ for $\mathrm{p} 70^{\mathrm{S} 6 \mathrm{k}}$ and $4 \mathrm{E}-\mathrm{BP} 1 ; n=5$ for mTOR, S6 and eEF2). ${ }^{*} P<0.05,{ }^{* *} P<0.01,{ }^{* * *} P<0.001$ vs. control 


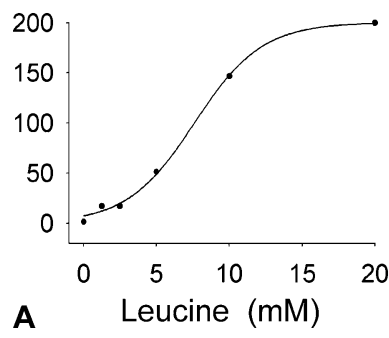

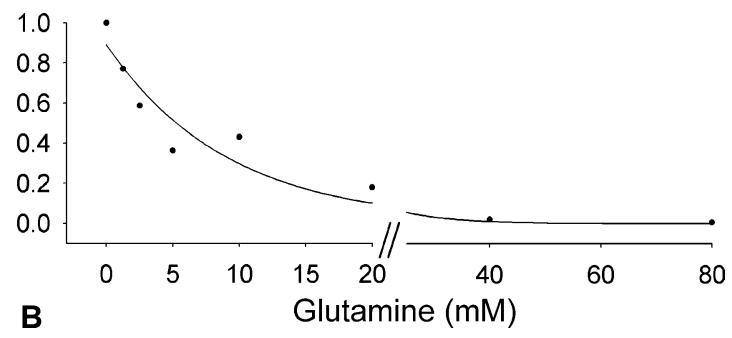

Fig. 2. Dose-response curves. Effect of increasing doses of leucine $(\mathbf{A}, 0-20 \mathrm{mM})$ and glutamine $(\mathbf{B}, 0-80 \mathrm{mM})$ on the phosphorylation state of $\mathrm{p} 70^{\mathrm{S} 6 \mathrm{k}}$ after $30 \mathrm{~min}$ ed 'gamma' form $(P<0.001$, Fig. 1B). This is in relation to the increase in the phosphorylation state of mTOR on both Ser $2448(P<0.01$, Fig. 1C) and Ser $2481\left(P<0.01\right.$, Fig. 1D). The leucine-induced $\mathrm{p} 70^{\mathrm{S} 6 \mathrm{k}}$ activation resulted to the expected increase in phosphorylation state of S6 on Ser 235/236 $(+70 \%, P<0.01$, Fig. 1E). By contrast, $5 \mathrm{mM}$ glutamine decreased the phosphorylation state of $\mathrm{p} 70^{\mathrm{S} 6 \mathrm{k}}$ by $80 \% \quad(P<0.001$, Fig. 1A) and the percentage of 4E-BP1 in 'gamma' form by $40 \%(P<0.01$, Fig. 1B). The inhibition induced by glutamine was also observed on mTOR but only on Ser $2448(P<0.05$, Fig. 1C) and not on Ser 2481 (Fig. 1D). The effects of leucine and glutamine on the phosphorylation state of $\mathrm{p} 70^{\mathrm{S} 6 \mathrm{k}}$ were dose-dependent. The more leucine was added to the medium, the more $\mathrm{p} 70^{\mathrm{S} 6 \mathrm{k}}$ was phosphorylated reaching a maximum at about $15-20 \mathrm{mM}$ (Fig. 2A). Inversely, the more glutamine, the larger inhibition on $\mathrm{p} 70^{\mathrm{S} 6 \mathrm{k}}$ was observed (Fig. 2B).
When leucine and glutamine were combined, the effect of leucine was predominant, overtaking the inhibition exerted by glutamine. Indeed, after the addition of $5 \mathrm{mM}$ leucine and $5 \mathrm{mM}$ glutamine, the phosphorylation state of $\mathrm{p} 70^{\mathrm{S} 6 \mathrm{k}}$ was increased more than 10 fold $(P<0.001$, Fig. 1A) and the percentage of the 'gamma' form of 4E-BP1 was nearly doubled $(P<0.001$, Fig. 1B). Similar results were obtained on mTOR phosphorylation, on both Ser $2448(P=0.06$, Fig. 1C) and Ser $2481(P<0.01$, Fig. 1D) and on S6 $(P<0.05$, Fig. 1E).

In contrast with the mTOR-mediated pathway, the phosphorylation state of eEF2 on Thr 56 was unaffected by either amino acid or the combination of both (Fig. 1F).

\subsection{Effect of leucine and glutamine on proteins regulating the mTOR pathway}

Leucine and glutamine, alone or in combination, did not affect the activity of PKB (Fig. 3A) and AMPK (Fig. 3B).

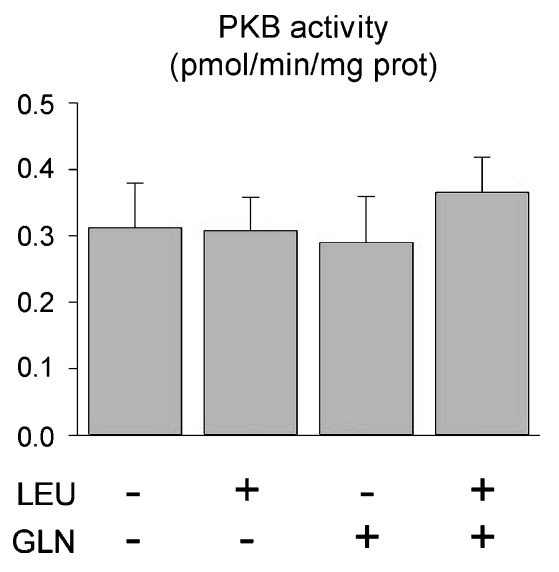

A

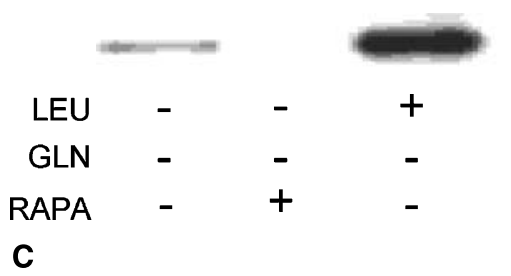

AMPK activity (pmol/min/mg prot)

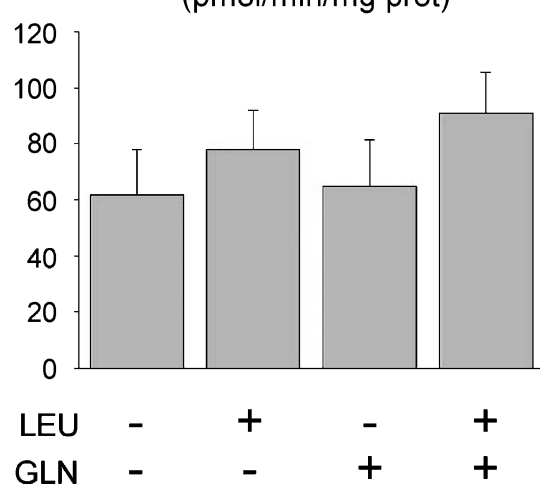

B

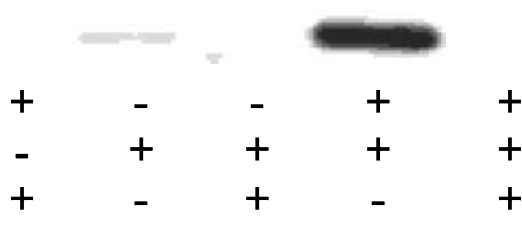

Fig. 3. Effect of leucine, glutamine, alone or in combination, on proteins regulating the mTOR pathway. PKB (A) and AMPK (B) activity. Results are expressed as the means \pm SEM ( $n=9$ for PKB; $n=6$ for AMPK). (C) Effect of rapamycin on the phosphorylation state of $\mathrm{p} 70^{\mathrm{s} 6 \mathrm{k}}$. Cells were preincubated with rapamycin $(100 \mathrm{nM})$ for $15 \mathrm{~min}$ before being incubated for $30 \mathrm{~min}$ as indicated. $L E U$ leucine; $G L N$ glutamine; $R A P A$ rapamycin 
The absence of modification of AMPK activity was confirmed by an unchanged ACC phosphorylation state (Ser 79) (data not shown). To evaluate the implication of the rapamycin-sensitive part of the mTOR pathway in the response to leucine and glutamine, $\mathrm{C}_{2} \mathrm{C}_{12}$ cells were incubated with $100 \mathrm{nM}$ rapamycin (Fig. 3C). In all conditions,

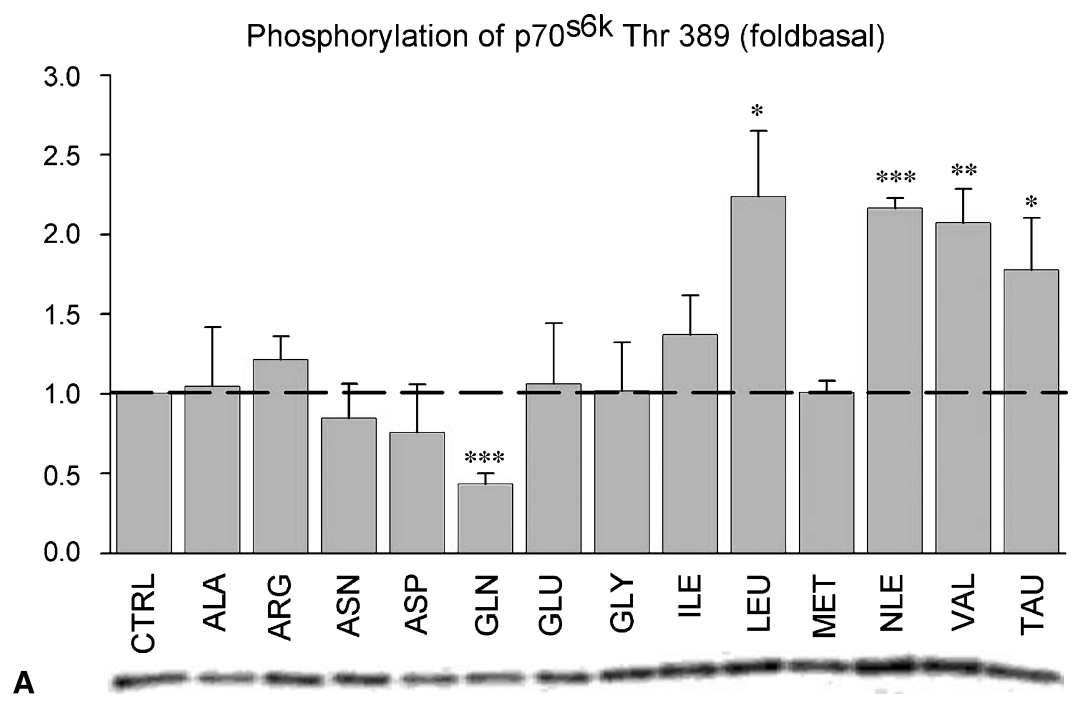

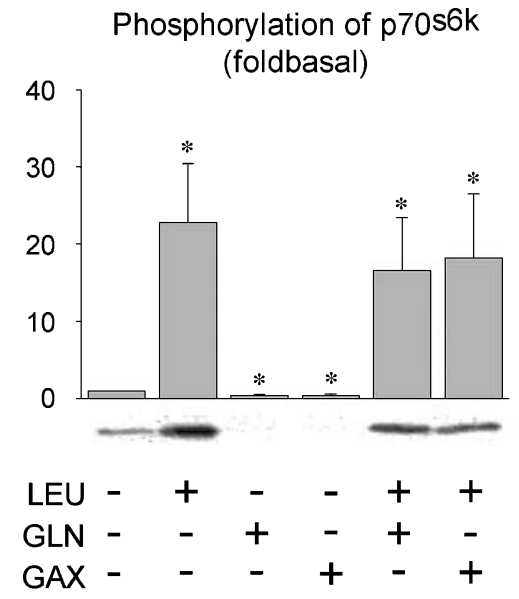

B

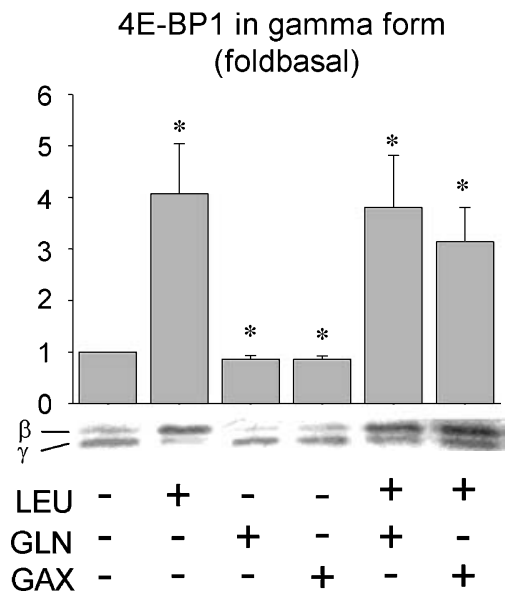

C
Fig. 4. Specificity of glutamine. (A) Effect of different amino acids on the phosphorylation state of $\mathrm{p} 70^{\mathrm{S} 6 \mathrm{k}}$ for $30 \mathrm{~min}$. CTRL control conditions; $A L A$ alanine; $A R G$ arginine; $A S N$ asparagine; $A S P$ aspartic acid; $G L N$ glutamine; $G L U$ glutamic acid; $G L Y$ glycine; ILE isoleucine; $L E U$ leucine; $M E T$ methionine; $N L E$ norleucine; $V A L$ valine; TAU taurine. Results are expressed as the means $\pm \operatorname{SEM}(n=3)$ and relative to the control conditions represented by the dashed line. $(\mathbf{B}, \mathbf{C})$ Effect of leucine $(L E U)$, glutamine $(G L N)$, GlutaMAX ${ }^{\mathrm{TM}}(G A X)$, alone or in different combinations, on the phosphorylation state of $\mathrm{p} 70^{\mathrm{S} 6 \mathrm{k}}$ on Thr 389 (B) and on the percentage of 4E-BP1 in gamma form (C) after an incubation period of $30 \mathrm{~min}$. Results are expressed as the means \pm SEM $(n=3) . \quad{ }^{*} P<0.05$, ${ }^{* *} P<0.01,{ }^{* * *} P<0.001$ vs. control
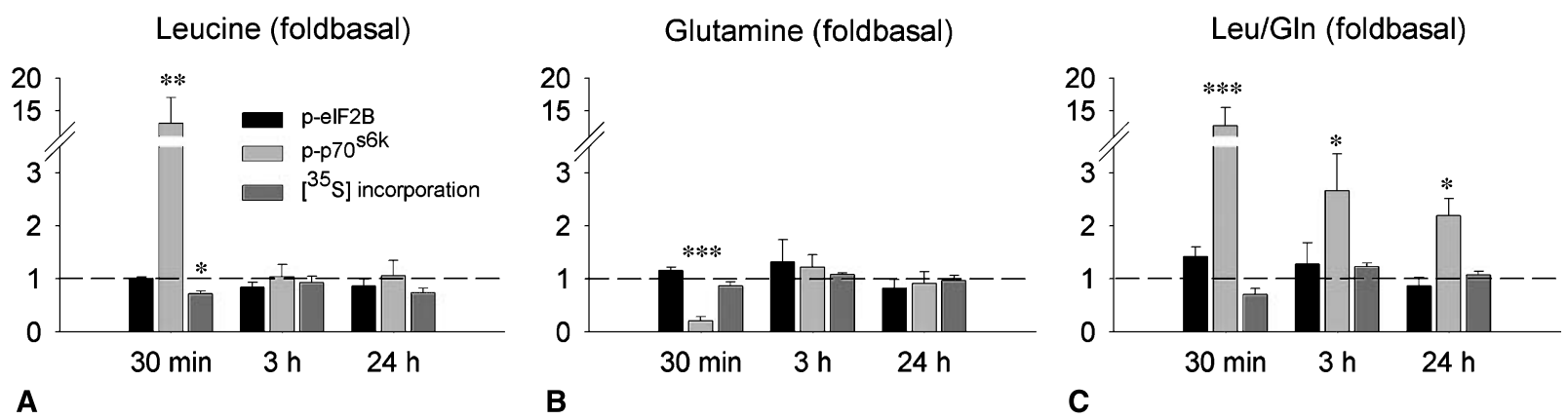

Fig. 5. Effect of leucine, glutamine, alone or in combination on the incorporation of labelled $\left[{ }^{35} \mathrm{~S}\right]$ methionine/cysteine and the phosphorylation state of p70 ${ }^{\mathrm{S} 6 \mathrm{k}}$ and eIF2B. The incorporation of labelled $\left[{ }^{35} \mathrm{~S}\right]$ methionine/cysteine $(n=4)$ and the phosphorylation state of p70 ${ }^{\mathrm{S} 6 \mathrm{k}}$ on Thr 389 and eIF2B on Ser $535(n=3)$ were quantified after $30 \mathrm{~min}, 1 \mathrm{~h}$ and $24 \mathrm{~h}$ of incubation with $5 \mathrm{mM}$ leucine $(\mathbf{A}), 5 \mathrm{mM}$ glutamine (B) and with both $5 \mathrm{mM}$ leucine (Leu) and $5 \mathrm{mM}$ glutamine (Gln) (C). Results are expressed as the means \pm SEM and relative to the control conditions represented by the dashed line. ${ }^{*} P<0.05,{ }^{* *} P<0.01,{ }^{* * *} P<0.001$ vs. control same time 
the $\mathrm{p} 70^{\mathrm{S} 6 \mathrm{k}}$ phosphorylation was totally abolished in the presence of rapamycin, indicating that at least the action of leucine is rapamycin-dependent.

\subsection{Effect of other amino acids}

$\mathrm{C}_{2} \mathrm{C}_{12}$ cells were also incubated with alanine, arginine, asparagine, aspartic acid, glutamic acid, glycine, isoleucine, methionine, norleucine, valine and taurine in order to test if other amino acids could also modify the phosphorylation state of $\mathrm{p} 70^{\mathrm{S} 6 \mathrm{k}}$ (Fig. 4A). The concentration used for each amino acid was $5 \mathrm{mM}$. None of them decreased the $\mathrm{p} 70^{\mathrm{S} 6 \mathrm{k}}$ phosphorylation state, whereas valine $(P<0.01)$, taurine $(P<0.05)$ and norleucine $(P<0.001)$, but not isoleucine, were able to increase it (Fig. 4A). In the same way, the effect of GlutaMAX ${ }^{\mathrm{TM}}$ (Life Technologies, Merelbeke, Belgium), a dipeptide composed of glutamine and alanine which reduces glutamine degradation into glutamic acid and ammonia, was studied. Like glutamine, GlutaMAX ${ }^{\mathrm{TM}}$ strongly decreased the phosphorylation state of $\mathrm{p}^{\mathrm{S} 6 \mathrm{k}}(P<0.05$, Fig. 4B) and 4E-BP1 $(P<0.05$, Fig. 4C).

\subsection{Effect of leucine and glutamine on $\left[{ }^{35}\right.$ S] labelled methionine/cysteine incorporation}

Whereas the phosphorylation state of $\mathrm{p} 70^{\mathrm{S} 6 \mathrm{k}}$ is often used as a marker of protein synthesis, Fig. 5 clearly shows that the incorporation of $\left[{ }^{35} \mathrm{~S}\right]$ labelled methionine/cysteine did not follow the phosphorylation state of $\mathrm{p} 70^{\mathrm{S} 6 \mathrm{k}}$ in the present study. The phosphorylation state of $\mathrm{p} 70^{\mathrm{S} 6 \mathrm{k}}$ was increased by leucine alone (12 fold, $P<0.01)$ and was decreased by glutamine alone $(-80 \%, P<0.001)$ after an incubation period of $30 \mathrm{~min}$ and it returned to basal level after 3 and $24 \mathrm{~h}$ (Fig. 5A). In the presence of both leucine and glutamine, $\mathrm{p} 70^{\mathrm{S} 6 \mathrm{k}}$ was more phosphorylated than in control conditions at each time point studied $(P<$ 0.05 , Fig. 5C). In contrast to what happened with the p70 ${ }^{\mathrm{S} 6 \mathrm{k}}$ phosphorylation state, the incorporation of $\left[{ }^{35} \mathrm{~S}\right]$ labelled methionine/cysteine was decreased by $25 \%$ after $30 \mathrm{~min}$ in cells incubated with $5 \mathrm{mM}$ leucine alone $(P<0.05$, Fig. 5A) and it was not altered by glutamine alone or by the combination of leucine and glutamine.

\subsection{Effect of leucine and glutamine on muscle-specific mRNA levels}

Since the mTOR pathway has also been shown to be involved in myogenesis (Park et al., 2005) and in the regulation of gene transcription by amino acid (Erbay

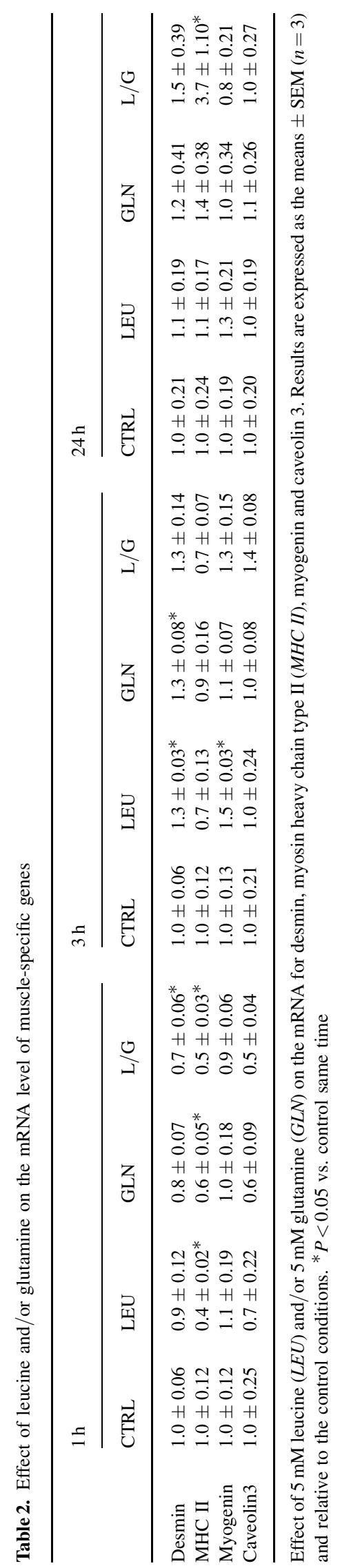


et al., 2003), we analyzed the effect of leucine and glutamine on the expression of several muscle-specific genes. The mRNA level for MHC II was decreased after $1 \mathrm{~h}$ by leucine $(-60 \%)$ and glutamine $(-40 \%)$ alone as well as by both amino acids together $(-50 \%)(P<0.05$, Table 2$)$. After the same period of incubation, the combination of leucine and glutamine also repressed the expression of desmin mRNA $(-30 \%, P<0.05)$. After $3 \mathrm{~h}$, the level of desmin mRNA was increased by leucine and glutamine alone $(+30 \%, P<0.05)$ and the level of myogenin mRNA by leucine $(+50 \%, P<0.05)$. After $24 \mathrm{~h}$, the mRNA level for MHC II was increased by 3.7 fold when leucine and glutamine were combined $(P<0.05)$. Caveolin 3 mRNA was not altered by leucine and/or glutamine.

\section{Discussion}

In this study, it is reported that leucine and glutamine have opposite effects on the mTOR pathway in myogenic $\mathrm{C}_{2} \mathrm{C}_{12}$ cells (Fig. 6). Like in other cell types (Fox et al.,

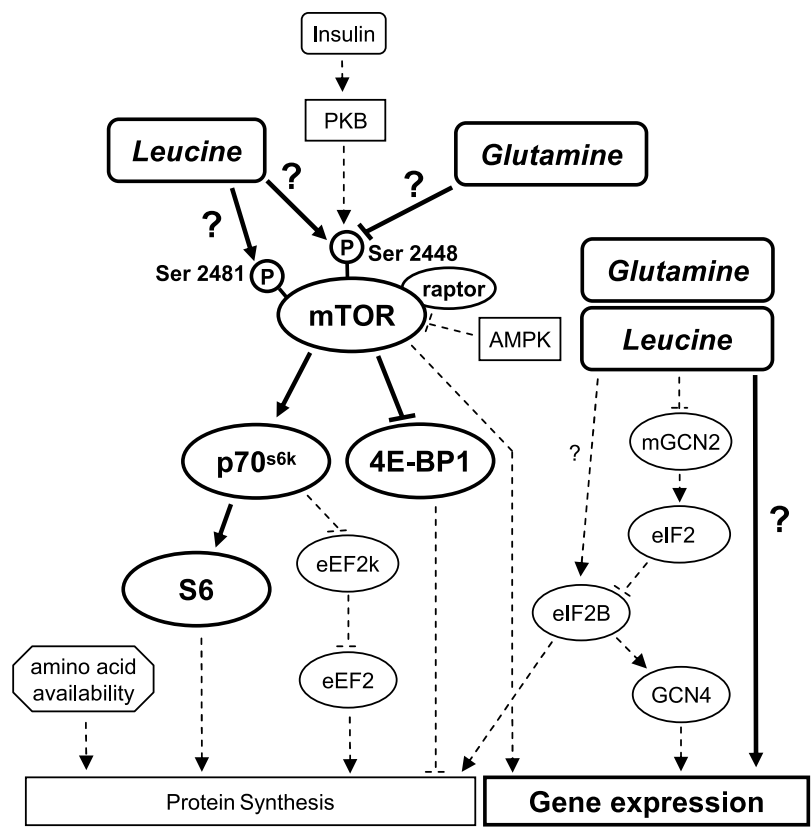

Fig. 6. Model for the control of the mTOR pathway, protein synthesis and gene expression by leucine and glutamine in $\mathrm{C}_{2} \mathrm{C}_{12}$ cells. $P K B$ protein kinase $\mathrm{B}$; $m T O R$ mammalian target of rapamycin; raptor regulatory associated protein to $\mathrm{mTOR}$; $A M P K$ AMP-activated protein kinase; $p 70^{S 6 k}$ p70 ribosomal S6 kinase; $4 E-B P 1$ eukaryotic initiation factor 4E-binding protein 1 ; eEF2 $k$ eukaryotic elongation factor 2 kinase; $e E F 2$ eukaryotic elongation factor 2; $S 6$ ribosomal protein $\mathrm{S} 6$; $m G C N 2$ mammalian general control non-derepressible kinase $2 ;$ eIF $2 \alpha$ eukaryotic initiation factor 2 alpha; eIF $2 \beta$ eukaryotic initiation factor 2B; GCN4 general control non-derepressible kinase 4. Bold lines effect of leucine and/or glutamine; dashed lines no effect of leucine and/or glutamine or untested
1998; Xu et al., 1998; Kimball et al., 1999; Krause et al., 2002), leucine increased the phosphorylation state of p70 ${ }^{\mathrm{S} 6 \mathrm{k}}$ and $4 \mathrm{E}-\mathrm{BP} 1$ in our $\mathrm{C}_{2} \mathrm{C}_{12}$ cells. However, leucine only transiently affected $\mathrm{p} 70^{\mathrm{S} 6 \mathrm{k}}$ since, after $3 \mathrm{~h}$, the phosphorylation state of the latter returned to basal values (Fig. 5). More strikingly, glutamine exerted an opposite transient effect, reducing the phosphorylation state of $\mathrm{p} 70^{\mathrm{S} 6 \mathrm{k}}$ and $4 \mathrm{E}-\mathrm{BP} 1$, whereas this amino acid is known to be a major activator of $\mathrm{p} 70^{\mathrm{S} 6 \mathrm{k}}$ in hepatocytes (Krause et al., 2002). Therefore, the action of glutamine on the phosphorylation state of $\mathrm{p} 70^{\mathrm{S} 6 \mathrm{k}}$ seems to be specific to the cell type studied, glutamine being able to exert opposite effects in two different cell types. Moreover, none of the other amino acids tested decreased the phosphorylation state of $\mathrm{p} 70^{\mathrm{S} 6 \mathrm{k}}$, suggesting that glutamine has a specific action in $\mathrm{C}_{2} \mathrm{C}_{12}$ cells (Fig. 4A). The dephosphorylation induced by glutamine was probably not caused by its transformation into glutamate in the medium. Even if glutamate could have been transported into muscle cells (Rennie et al., 1996), it did not alter the phosphorylation state of $\mathrm{p} 70^{\mathrm{S} 6 \mathrm{k}}$ (Fig. 4A). Moreover, GlutaMAX ${ }^{\mathrm{TM}}$, which is a stabilized form of glutamine with the structure of a dipeptide L-alanyl-L-glutamine, mimicked the effect of glutamine by reducing the phosphorylation of $\mathrm{p} 70^{\mathrm{S} 6 \mathrm{k}}$ and 4E-BP1 (Fig. 4B and C). These results strengthen the hypothesis that glutamine itself rather than the products of its degradation, e.g. glutamic acid and ammonia, is responsible for the inhibition observed on the mTORmediated pathway.

Following these unexpected data, we tried to understand further how leucine and glutamine exerted their respective effect on mTOR and the physiological role of this leucine- and glutamine-induced signalling. Several proteins have been shown to regulate mTOR; PKB, AMPK and raptor being of the highest importance (Fig. 6). PKB is known to activate whereas AMPK is known to inhibit (Kimura et al., 2003) the mTOR pathway, respectively. However, neither leucine nor glutamine was able to modify the activity of these kinases, demonstrating that the signalling of both amino acids is independent of PKB and AMPK (Fig. 3A and B). Leucine signalling through mTOR is rapamycin-dependent as demonstrated by the total inhibition of the action of this amino acid by the addition of rapamycin (Fig. 3C). The binding of rapamycin to its intracellular receptor, FK506-binding protein, allows it to interact specifically with mTOR and to prevent the binding of raptor to mTOR to form the mTORC1 complex (Kim et al., 2002). Raptor is known to mediate the activation of $\mathrm{p} 70^{\mathrm{S} 6 \mathrm{k}}$ by nutrients and the increase in cell size. Our data confirm that raptor plays a 
key role in the action of leucine on the mTOR pathway in $\mathrm{C}_{2} \mathrm{C}_{12}$ cells.

As $p 70^{\mathrm{S} 6 \mathrm{k}}$ is generally believed to be a key regulator of protein synthesis initiation, the present study investigated whether the activation induced by leucine and the inhibition exerted by glutamine on the phosphorylation state of $\mathrm{p} 70^{\mathrm{S} 6 \mathrm{k}}$ had any effect on the incorporation of labelled methionine/cysteine. Unexpectedly, the incorporation of labelled methionine/cysteine was only transiently affected by leucine and was not modified by glutamine (Fig. 5). We observed a $25 \%$ decrease in labelled methionine/ cysteine incorporation induced by leucine after $30 \mathrm{~min}$, which is contrary to its effect on the $\mathrm{mTOR} / \mathrm{p} 70^{\mathrm{S} 6 \mathrm{k}}$ pathway. Our results on the phosphorylation of the ribosomal S6 subunit and eEF2 might partially explain those on labelled methionine/cysteine incorporation. Although both lying downstream of $\mathrm{p} 70^{\mathrm{S} 6 \mathrm{k}}$ in the regulation of protein synthesis, S6 was only slightly affected and eEF2 not modified at all by leucine and glutamine (Fig. 1E and F). Since eIF2B has also been proposed as a key regulator of protein synthesis (Kimball et al., 1998), its phosphorylation state after leucine and glutamine incubation was analyzed (Fig. 5). But, in contrast to $\mathrm{p} 70^{\mathrm{S} 6 \mathrm{k}}$, leucine and glutamine did not affect its phosphorylation state, ruling out its involvement in the decrease in labelled methionine/cysteine incorporation induced by leucine after $30 \mathrm{~min}$. Taken together, our data indicate that a change in the phosphorylation state of $\mathrm{p} 70^{\mathrm{S} 6 \mathrm{k}}$ on Thr 389 does not necessarily lead to a subsequent modification of the phosphorylation of its downstream targets and to a change in amino acid incorporation. These data are noteworthy since previous experiments showing modifications in protein metabolism were based on amino acid restriction (Mordier et al., 2000) or were carried out during the proliferation phase and high protein turnover (Kimball et al., 1999; Du et al., 2007). By contrast, the present experiments were carried out during the differentiation phase characterized by a lower protein translation rate.

Since amino acid incorporation was only affected to a minor extent by leucine, the study examined whether the changes in $\mathrm{p} 70^{\mathrm{S} 6 \mathrm{k}}$ phosphorylation state could alter gene expression (Fig. 6). Moreover, amino acids have recently been shown to control IGF-II transcription and myogenesis through mTOR/p70 ${ }^{\mathrm{S} 6 \mathrm{k}}$ pathway (Erbay et al., 2003). To characterize better the possible involvement of amino acids in the regulation of gene expression and myogenesis in $\mathrm{C}_{2} \mathrm{C}_{12}$ cells, we analyzed the mRNA level of musclespecific genes after incubation with leucine and/or glutamine (Table 2). Although leucine and/or glutamine modified the mRNA levels of desmin, myogenin and
MHC II, the changes did not follow the phosphorylation state of the $\mathrm{mTOR} / \mathrm{p} 70^{\mathrm{S} 6 \mathrm{k}}$ pathway, contrary to our hypothesis, suggesting that the latter is probably not involved in the control of the transcription of these genes. Other pathways have been proposed to mediate the effect of amino acids on gene expression. Although they were not tested in this study, it seems likely that they do not contribute to the present results. The hexosamine signalling pathway, through glucosamine-6-phosphate and subsequent O-linked glycosylation of various proteins, seems to play an important role in regulating gene expression (Marshall, 2006). Since glutamine is used as an amino donor to convert fructose-6-phosphate to glucosamine-6phosphate (Marshall, 2006), it plays an important role in the regulation of gene expression induced by the hexosamine signalling pathway (Brasse-Lagnel et al., 2003). However, this pathway essentially regulates the expression of genes encoding proteins that are involved in controlling the insulin-stimulated glucose transport system and triglyceride synthesis (Marshall, 2006). Amino acid deprivation has also been shown to cause ER (endoplasmic reticulum) stress and to induce gene expression via phosphorylation of eIF2 $\alpha$ and eIF2B (Abcouwer et al., 2002; Kilberg and Barbosa-Tessmann, 2002). However, eIF2B was not affected by additional leucine and/or glutamine (Fig. 5), ruling out a possible implication of ER stress in the regulation of gene expression in the present study.

In conclusion, leucine activates the mTOR pathway in myogenic $\mathrm{C}_{2} \mathrm{C}_{12}$ cells. By contrast to leucine, glutamine inhibits this pathway by dephosphorylating the Ser 2448 of mTOR and decreasing the phosphorylation state of $\mathrm{p} 70^{\mathrm{S} 6 \mathrm{k}}$ and 4E-BP1. Whilst the phosphorylation state of $\mathrm{p} 70^{\mathrm{S} 6 \mathrm{k}}$ is usually related to the rate of protein synthesis, the incorporation of labelled methionine/cysteine remained unaffected by glutamine and was only transiently decreased by leucine. In line with the recent conception of gene expression regulation by amino acids, leucine and glutamine affected the mRNA levels of desmin, myogenin and MHC II in a time-dependent manner but unrelated to their effects on the mTOR/p70 ${ }^{\mathrm{S} 6 \mathrm{k}}$ pathway in $\mathrm{C}_{2} \mathrm{C}_{12}$ cells.

\section{Acknowledgements}

The authors would like to thank Martine De Cloedt for her technical support. This work was supported by the Belgian Fund for Medical Research (3.4574.03, 1.5269.05 and 3.4585.06) and by the Belgian Federal Interuniversity Attraction Poles programme (P5). Luc Bertrand is Research Associate of the National Fund for Scientific Research, Belgium. Sandrine Horman is supported by EU contracts no QLG1-CT-200101488 (AMPDIAMET) and LSHM-CT-2004-005272 (EXGENESIS). 
Cossette Sanchez Canedo is supported by the "Coopération Universitaire au Développement" (Belgium).

\section{References}

Abcouwer SF, Marjon PL, Loper RK, Vander Jagt DL (2002) Response of VEGF expression to amino acid deprivation and inducers of endoplasmic reticulum stress. Invest Ophthalmol Vis Sci 43: 2791-2798

Alessi DR, Caudwell FB, Andjelkovic M, Hemmings BA, Cohen P (1996) Molecular basis for the substrate specificity of protein kinase B; comparison with MAPKAP kinase-1 and p70 S6 kinase. FEBS Lett 399: $333-338$

Bertrand L, Alessi DR, Deprez J, Deak M, Viaene E, Rider MH, Hue L (1999) Heart 6-phosphofructo-2-kinase activation by insulin results from Ser-466 and Ser-483 phosphorylation and requires 3-phosphoinositide-dependent kinase-1, but not protein kinase B. J Biol Chem 274: 30927-30933

Brasse-Lagnel C, Fairand A, Lavoinne A, Husson A (2003) Glutamine stimulates argininosuccinate synthetase gene expression through cytosolic O-glycosylation of Sp1 in Caco-2 cells. J Biol Chem 278: 52504-52510

Deldicque L, Theisen D, Francaux M (2005) Regulation of mTOR by amino acids and resistance exercise in skeletal muscle. Eur J Appl Physiol 94: 1-10

Du M, Shen QW, Zhu MJ, Ford SP (2007) Leucine stimulates mammalian target of rapamycin signalling in $\mathrm{C}_{2} \mathrm{C}_{12}$ myoblasts in part through inhibition of adenosine monophosphate-activated protein kinase. J Anim Sci 85: 919-927

Erbay E, Park IH, Nuzzi PD, Schoenherr CJ, Chen J (2003) IGF-II transcription in skeletal myogenesis is controlled by mTOR and nutrients. J Cell Biol 163: 931-936

Fox HL, Kimball SR, Jefferson LS, Lynch CJ (1998) Amino acids stimulate phosphorylation of p70S6k and organization of rat adipocytes into multicellular clusters. Am J Physiol 274: C206-C213

Jefferson LS, Kimball SR (2003) Amino acids as regulators of gene expression at the level of mRNA translation. J Nutr 133: 2046S-2051S

Kilberg MS, Barbosa-Tessmann IP (2002) Genomic sequences necessary for transcriptional activation by amino acid deprivation of mammalian cells. J Nutr 132: 1801-1804

Kim DH, Sarbassov DD, Ali SM, King JE, Latek RR, ErdjumentBromage H, Tempst P, Sabatini DM (2002) mTOR interacts with raptor to form a nutrient-sensitive complex that signals to the cell growth machinery. Cell 110: 163-175

Kimball SR, Horetsky RL, Jefferson LS (1998) Implication of eIF2B rather than eIF4E in the regulation of global protein synthesis by amino acids in L6 myoblasts. J Biol Chem 273: 30945-30953

Kimball SR, Shantz LM, Horetsky RL, Jefferson LS (1999) Leucine regulates translation of specific mRNAs in L6 myoblasts through mTOR-mediated changes in availability of eIF4E and phosphorylation of ribosomal protein S6. J Biol Chem 274: 11647-11652
Kimura N, Tokunaga C, Dalal S, Richardson C, Yoshino K, Hara K, Kemp BE, Witters LA, Mimura O, Yonezawa K (2003) A possible linkage between AMP-activated protein kinase (AMPK) and mammalian target of rapamycin (mTOR) signalling pathway. Genes Cells 8: 65-79

Krause U, Bertrand L, Maisin L, Rosa M, Hue L (2002) Signalling pathways and combinatory effects of insulin and amino acids in isolated rat hepatocytes. Eur J Biochem 269: 3742-3750

Marshall S (2006) Role of insulin, adipocyte hormones, and nutrientsensing pathways in regulating fuel metabolism and energy homeostasis: a nutritional perspective of diabetes, obesity, and cancer. Sci STKE 2006: re7

Marsin AS, Bertrand L, Rider MH, Deprez J, Beauloye C, Vincent MF, Van den Berghe G, Carling D, Hue L (2000) Phosphorylation and activation of heart PFK-2 by AMPK has a role in the stimulation of glycolysis during ischaemia. Curr Biol 10: 1247-1255

Mordier S, Deval C, Bechet D, Tassa A, Ferrara M (2000) Leucine limitation induces autophagy and activation of lysosome-dependent proteolysis in $\mathrm{C}_{2} \mathrm{C}_{12}$ myotubes through a mammalian target of rapamycin-independent signalling pathway. J Biol Chem 275: 29900-29906

Nakajo T, Yamatsuji T, Ban H, Shigemitsu K, Haisa M, Motoki T, Noma K, Nobuhisa T, Matsuoka J, Gunduz M, Yonezawa K, Tanaka N, Naomoto Y (2005) Glutamine is a key regulator for amino acid-controlled cell growth through the mTOR signalling pathway in rat intestinal epithelial cells. Biochem Biophys Res Commun 326: 174-180

Park IH, Erbay E, Nuzzi P, Chen J (2005) Skeletal myocyte hypertrophy requires mTOR kinase activity and S6K1. Exp Cell Res 309: 211-219

Peng T, Golub TR, Sabatini DM (2002) The immunosuppressant rapamycin mimics a starvation-like signal distinct from amino acid and glucose deprivation. Mol Cell Biol 22: 5575-5584

Proud CG (2002) Regulation of mammalian translation factors by nutrients. Eur J Biochem 269: 5338-5349

Rennie MJ, Ahmed A, Khogali SE, Low SY, Hundal HS, Taylor PM (1996) Glutamine metabolism and transport in skeletal muscle and heart and their clinical relevance. J Nutr 126: 1142S-1149S

Rohde J, Heitman J, Cardenas ME (2001) The TOR kinases link nutrient sensing to cell growth. J Biol Chem 276: 9583-9586

Xia Y, Wen HY, Young ME, Guthrie PH, Taegtmeyer H, Kellems RE (2003) Mammalian target of rapamycin and protein kinase A signalling mediate the cardiac transcriptional response to glutamine. J Biol Chem 278: $13143-13150$

Xu G, Kwon G, Marshall CA, Lin TA, Lawrence JC Jr, McDaniel ML (1998) Branched-chain amino acids are essential in the regulation of PHAS-I and p70 S6 kinase by pancreatic beta-cells. A possible role in protein translation and mitogenic signalling. J Biol Chem 273: 28178-28184

Authors' address: Marc Francaux, Département d'Education Physique et de Réadaptation, Université catholique de Louvain, Place Pierre de Coubertin 1, B-1348 Louvain-la-Neuve, Belgium,

Fax: +32-10-47 20 93, E-mail: marc.francaux@uclouvain.be 